\title{
TROPOS DEL VIAJE A LA NATURALEZA SILVESTRE EN EL MAL DE LA TAIGA (2012) DE CRISTINA RIVERA GARZA
}

\author{
Tropos trip to the wild nature in El mal de la taiga (2012) \\ by Cristina Rivera Garza
}

Grażyna Walczak*

\begin{abstract}
RESUMEN
En este artículo se analizan los tropos del viaje a la naturaleza virgen en la novela breve de Cristina Rivera Garza, El mal de la taiga (2012). Utilizados previamente por otros escritores, tales como José Eustasio Rivera, Rómulo Gallegos o Alejo Carpentier, los motivos del periplo se desplazan y se transforman, permitiendo a la autora expresar preocupaciones que atañen al ser humano universal: el individuo ante la naturaleza desconocida que abarca tanto el espacio geográfico, como el cuerpo humano. Los tropos que se examinan incluyen la penetración del espacio extraño, la enfermedad, la mujer arquetípica y las figuras de los cuentos fantásticos. El análisis revela los resultados dañinos de las pasiones y obsesiones humanas sobre las diversas formas de vida del planeta.

Palabras clave: naturaleza, taiga, viaje, parodia, obsesiones.
\end{abstract}

\begin{abstract}
This article analyzes the tropes of the journey to the virginal nature, in the short novel by Cristina Rivera Garza, El mal de la taiga (2012). Used previously by other writers, such as José Eustasio Rivera, Rómulo Gallegos o Alejo Carpentier, the motives of the trips are being displaced and transformed, allowing the author express worries that concern the universal human beings: the individual in front of the unknown nature that includes the geographical space, as well as the human body. The tropes examined here include the penetration of the strange territory, the illness, the archetypal woman, and the figures from the fantastic stories. The analysis reveals the damaging results of the human passions and obsessions on the diverse form of life in the planet.
\end{abstract}

Key Words: nature, taiga, journey, parody, obsessions.

Profesora asistente de la Universidad Valdosta State. USA.

Correo electrónico: guiyermin@hotmail.com

Recepción: 04/03/2014. Aceptación: 30/06/2014. 


\section{Introducción}

El motivo del viaje a la naturaleza silvestre aparece en la literatura hispanoamericana desde los relatos de los primeros europeos, quienes al incursionar en el paisaje americano lo describieron como un paraíso terrenal. Con el tiempo, las imágenes de los bosques tropicales benignos, poblados de habitantes pacíficos $\mathrm{y}$ amigables, han cambiado: en los reportes de los misioneros y colonizadores la selva se ha convertido en el misterioso y temible albergue de los "salvajes", ajeno a la civilización dominante. A lo largo de la época colonial, los escritos de los viajeros establecieron ciertos estereotipos sobre los parajes recónditos, que impregnaron el imaginario de los lectores, tales como la barbarie de los indios, la fecundidad, la enfermedad, la degeneración, la soledad, etc. A la llegada de la independencia, los escritores latinoamericanos ensalzaron los rasgos distintivos de la naturaleza de su tierra, estableciendo asimismo su propia identidad literaria. En sus ya clásicas novelas de la selva siguen apareciendo los tropos del viaje empleados anteriormente, sin embargo éstos emergen en sus novelas transformados por medio de la parodia (Wylie 2009: 16). Los textos son muchos; los más conocidos aparecen a principios del siglo XX: Green Mansions (1904) del escritor anglo-argentino, W.H. Hudson, los "Cuentos misioneros" (1914-1924) de Horacio Quiroga, La vorágine (1924), de José Eustasio Rivera, Canaima (1935), de Rómulo Gallegos y Los pasos perdidos (1953), de Alejo Carpentier. En sus obras, el "retorno" o la "emigración" a la naturaleza virgen brinda a los lectores la oportunidad de advertir los temores, esperanzas y conflictos relativos al ambiente silvestre, a la vez que permite conocer y comprender muchos de los problemas regionales y nacionales.

A casi cien años del apogeo de las novelas de la selva, los tropos del viaje a la inmensidad silvestre sufren una nueva metamorfosis paródica en la novela breve de Cristina Rivera Garza, El mal de la taiga (2012). Para comenzar, el destino ya no es la selva tropical, sino el bosque nórdico. De manera parecida, otros elementos reciben un giro que le permite a la autora expresar preocupaciones que atañen al ser humano universal: el individuo ante la naturaleza desconocida, que abarca tanto el espacio geográfico, como el de su propia persona. Los tropos que se emplean en el contexto de esa naturaleza multifacética. Estos son: la penetración del espacio extraño, la enfermedad, la mujer arquetípica y las criaturas fantásticas. El análisis de los diversos sentidos que incluyen estos tropos permite entender mejor los conflictos que causan las pasiones y obsesiones humanas tanto para el entorno natural, como para los individuos.

Cabe aclarar que bajo el concepto de la parodia se entiende aquí el uso de la estrategia narrativa multifacética que más que ridiculizar o subvertir los textos previos, usa la inversión. Según explica Linda Hutcheon, el término griego de esta táctica retórica incluye tanto la idea de contrariar, como la de añadir ideas a los sentidos originales (1985: 32). Es precisamente esa segunda función de la parodia que interesa en el presente análisis, ya que ésta no se enfoca en los posibles elementos lúdicos, sino que destaca la "repetición con diferencia", que agrega un sentido diferente al anterior, sin necesariamente excluir a aquél. Conviene tener en cuenta que este tipo de la parodia tiene mucho en común con la metáfora, puesto que "[b]oth require that the decoder construct a second meaning through inferences about surface statements and supplement the foreground with acknowledgement and knowledge of a backgrounded context" (Hutcheon 1985: 33-34).En otras palabras, en la interpretación de los tropos del viaje re-apropiados por Rivera Garza se deben tener en cuenta también algunos elementos de los significados anteriores. Conforme a ello, en el presente análisis se hacen referencias a algunas narraciones latinoamericanas y europeas, que hasta cierto punto quedan incluidas en los tropos del viaje usados en esta novela, tales como las ya mencionadas novelas de la selva y los cuentos infantiles de los hermanos Grimm.

Antes de pasar al análisis, conviene resumir la trama de El mal de la taiga: una detective acepta el trabajo que le fue encargado 
por un marido engañado y viaja a la taiga en compañía de un intérprete para encontrar y traer de regreso a la esposa infiel. La prófuga, en compañía de su amante, se adentra cada vez más al bosque de las antípodas, pero es posible seguirla gracias a las misteriosas noticias que de vez en cuando le envía a su esposo. Los nombres de los prófugos, así como de los lugares por los que éstos transitan no se conocen. Tampoco se conoce el de la narradora-protagonista, aunque se entiende que es la misma que aparece en otras novelas de Rivera Garza como una detective ${ }^{1}$. La falta de nombres es evidentemente una sugerencia de que los protagonistas son unos actantes en el sentido que lo usa Vladimir Propp, que pueden representar a cualquier persona $^{2}$. Pero también es una señal de que la estructura no es solamente el "simulacro del objeto" como la define Barthes, sino que llega a ser el objeto mismo (Pisonero1999: 46). Se trata de una estructura de la novela fragmentaria, donde la narración se teje entre la realidad y la imaginación, mezclando el reporte detectivesco con el diario personal, la memoria y la fantasía de la narradora, quien asimismo deja de ser fidedigna. Esa falta de veracidad ayuda; sin embargo a orientar el enfoque no en las personas y los hechos reales, sino en las ideas de lo posible y las impresiones. El énfasis en la estructura realza la importancia de descifrar la parodia contenida en los tropos para valorar mejor los significados nuevos. Esos significados no atañen a ninguna persona, región o nación en concreto, sino que se refieren al ser humano universal.

\section{La penetración de la naturaleza virgen}

En la tradición latinoamericana, el viaje hacia dentro de la naturaleza virgen no lleva las características de la popular tendencia norteamericana de nature writing ${ }^{3}$. Como observan algunos críticos literarios y ambientalistas, los escritores latinoamericanos ocupados en representar las realidades de índole social, política y cultural de su región no han prestado tanta atención a su entorno natural como para colocarlo de protagonista único e indisputable de sus textos: "cuando se trata de prestar atención a los cambios, conflictos y debates ambientales, la literatura latinoamericana no da la impresión de satisfacer estas expectativas" (Marcone 2007: 3). Sin embargo, aún si no se puede hablar de un corpus literario orientado hacia los problemas de medioambiente, la relación del ser humano con la naturaleza en la narrativa latinoamericana es bastante significativa. En las ya mencionadas novelas de la selva, la incursión en los parajes selváticos impresiona tanto por la descripción detallada de los ambientes naturales, como por conflictos sociales que descubre. La zona forestal se presenta como un lugar admirable, pero peligroso: la abundante vegetación abruma con sus imágenes de descomposición, sus insectos venenosos, sus reptiles taimados y sus animales sangrientos, todos prestos a hacerle daño al ser humano. Las condiciones del ambiente natural son, sin embargo, apenas una parte de las circunstanciasen contra de las cuales tienen que enfrentarse los protagonistas para sobrevivir, ya que el viaje revela también otros problemas, de índole social, mucho más preocupantes porque causados por los humanos. Por ejemplo, cuando el protagonista de $L a$ vorágine (1924), de José Eustasio Rivera, se interna en la selva amazónica colombiana en búsqueda de su amada, se convierte en testigo de las condiciones deplorables en que laboran los trabajadores de la industria del caucho convertidos en esclavos por parte de una empresa peruana. De manera parecida, en Canaima (1935), de Rómulo Gallegos, el problema que delata el viaje al corazón de la selva amazónica es principalmente el terror del caciquismo. A su vez, el protagonista de Los pasos perdidos (1953) de Alejo Carpentier busca en la selva del Orinoco los instrumentos musicales para explicar el origen de la música en las sociedades selváticas; su viaje es un repaso de los principios organizativos de su propia sociedad y advertencia de los peligros que esperan la naciente civilización si sigue por las mismas vías del progreso ${ }^{4}$. La vida de los personajes está ligada a la naturaleza virgen, a 
la vez que su lucha en contra de las adversidades del entorno cobra significado en el contexto social más amplio, aplicable a la nación o a la humanidad entera.

Hasta cierto punto, el viaje al bosque boreal en El mal de la taiga repite el esquema empleado en las novelas de la selva, ya que revela los aspectos desconocidos u olvidados del ambiente natural, a la vez que muestra de los conflictos provocados por los humanos. El paso de la narradora por la taiga abre la posibilidad de hacer observaciones sobre el entorno. Para comenzar, destaca el desengaño que sufre al internarse en la taiga. Su imaginación sobre esa zona estaba forjada por las imágenes que había visto en las pinturas que adornaban las paredes de su cafetería favorita en una ciudad de la costa mexicana. En ellas se apreciaba un bosque misterioso con las coníferas altas, en cuyo seno aparecían las pintorescas casitas de los leñadores. Sin embargo, al adentrarse en la arboleda, le sorprende la diferencia que percibe entre el paisaje idealizado de aquellas pinturas y la realidad. Se percata de otros aspectos prevalentes en los parajes de la taiga, no registrados en las imágenes, pero que resultan mucho más importantes para los que están dentro de este lugar: el frío penetrante, el ambiente hostil y la persistencia de los problemas humanos que no solo no son del dominio del entorno urbano, sino que se agudizan en el ambiente primitivo.

La narradora descubre que las pintorescas casitas son en realidad lugares incómodos e insalubres. No tienen luz, ni calefacción, salvo la proveniente de las estufas, ni tampoco servicios sanitarios satisfactorios: los habitantes tienen que usar letrinas fuera de sus casas aún en el invierno más crudo. El agua se saca con cubetas de los pozos que durante el invierno están congelados. Aunque no revela las condiciones trabajan los leñadores, el lector puede adivinarlas al hacer la conexión con las imágenes de sus viviendas, sus caras sucias y llenas de surcos, sus manos tiesas, y su ropa andrajosa. Son gente explotada por el capitalista de la región, que a miles de kilómetros de la civilización, teniendo de vecinos a los que a diario no comen más que papas, goza de una casa lujosa con una hermosa alberca azul. El capitalista, al contrario de los trabajadores, tiene luz eléctrica proveniente de su generador privado, muebles lujosos y goza de una comida nutritiva y deliciosa. Su papel social se refleja en su manera de comer la carne: "Recuerdo el movimiento de las mandíbulas, constante y atroz. Abrir y cerrar. Masticar. Deglutir” (Riverza Garza 2012: 57). La imagen se convierte en la metáfora del capitalismo que acaba con los organismos vivientes.

Sin embargo, la explotación capitalista no exime a las personas subordinadas de sus propias faltas. Los leñadores también son culpables de la explotación y abuso de los seres aún más débiles que ellos. Aún en este ambiente, aparentemente tan simple, existe la prostitución: "Después de todo, es casi desde la eternidad que las mujeres en desgracia han recurrido a sitios como en el que nos encontrábamos ya para sobrevivir en condiciones hostiles o ya con la creencia de que ahí conseguirían los recursos para escapar" (Riverza Garza 2012: 83). Además de explotar a las mujeres en los prostíbulos, se entretienen en ver el sexo de los menores. La detective, mareada por el efecto de la hipotermia, la luz de la cantina y el alcohol ingerido en la antesala, afirma no saber cómo narrar la escena, sin embargo describe un apareamiento de dos criaturas pequeñas puestas a la vista gozosa de los hombres de la cantina, según constata la narradora:

Creí que serían la encarnación de la delirante idea de algún varón en celo porque, sí, de hecho, las dos criaturas mínimas, de cabellos y piernas largas, se enredaban justo ahora en un abrazo que mucho tenía de sexual. Una se montaba, en efecto, sobre la otra. Otra le abría las piernas y entraba en su sexo con las manos y con la lengua. (Riverza Garza 2012: 85)

Los leñadores son culpables también de otros pecados, ya que organizan una cacería y le dan la muerte al niño salvaje, cuya única culpa era no acoplarse a la comunidad y andar libremente entre los árboles. Esta muerte se conecta, según la narradora, con su actividad habitual de todos los días, que es la destrucción del ente no humano, el bosque: 
Que los leñadores podrían ser gente circunspecta eso lo sabía o lo intuía, da lo mismo. Su cercanía a herramientas pesadas, punzocortantes, dentadas, eso debe tener algo que ver. El riesgo de su oficio. Su relación tan estrecha y tan paradójica, orgánica casi con el bosque al que matan y que, sin embargo, los alimenta. ¿Pasa todo esto por la mente de un leñador mientras tasajea y hiende y golpea la corteza?, me hice esa pregunta con frecuencia esos días. Me la contesté: pasa eso y tanto más. O pasaría. (Riverza Garza 2012: 68).

La tala de árboles es una actividad que los habitantes de la taiga han hecho desde siempre para sostenerse. Sin embargo dan lástima esos "árboles que, después de crecer por decenas de años, serían derribados sin contemplaciones" (Riverza Garza 2012: 91). Pero el corte de los pinos es apenas el ápice de los problemas que sufre el bosque, ya que lo siguen las imágenes de campamentos de personas recién llegadas de las ciudades, empecinadas en la búsqueda de otras riquezas, sobre todo el petróleo. La gente que empezó a poblar la taiga con sus tiendas de campaña, vestida en sus trajes térmicos, pronto va a construir una ciudad igual también en este lado. Según reporta el traductor de la detective, en otro extremo del mismo bosque existe la ciudad de metal sobre el lago, de la cual él es oriundo. Con esa imagen se abre una expectativa angustiante sobre el futuro del todavía prístino espacio natural al que la narradora ve - significativamente - por última vez, antes de abordar el avión de regreso.

El mal de la taiga revela también otros problemas, alusivos a la naturaleza humana, ya que la novela incluye referencias a otro viaje: el que emprenden los amantes prófugos. El transcurrido y los motivos de éste solo se conocen "de segunda mano", por la interpretación de los reportes que recibe la detective de otras personas, suplementados con su imaginación. La incursión en el bosque por parte de esas personas es paralela a su deseo sexual de la penetración. Su ansia del retorno a la naturaleza primitiva se traduce como el anhelo de llegar a un lugar donde las acciones no se rigen por la razón, sino por los deseos. La fuga significa el ansia de la libertad, de refugiarse en un lugar donde se puede realizar el yo propio, sin ataduras y exigencias de la civilización. Sin embargo, según se explica más adelante, su pasión es obsesiva y sinónima con la locura que causa estragos tanto para ellos mismos, como para su entorno.

\section{La enfermedad}

La expresión del mal en el título de la novela alude en primera instancia a una alteración de la salud que sufren los viajeros cuando se integran en el bosque boreal, así como la gente local cuando se extravía en él. La enfermedad se manifiesta con la hipotermia, inanición, angustia o delirio, o todo junto. Historias de tales casos se conocen ampliamente entre los habitantes de las zonas nórdicas y no necesitan mucha explicación, puesto que aún con poco conocimiento sobre el lugar, el sentido común advierte el peligro que significa para el cuerpo humano internarse en el ambiente tan hostil como la taiga, especialmente en las condiciones invernales. En la novela no faltan momentos donde se observa la perturbación en la salud de la narradora: las manos heladas, el agotamiento, la respiración cortada, la vista borrosa y los sentidos alterados. Estos síntomas son empero solo avisos de lo que podría sucederle si le llegara a afectar de lleno el temido mal de la taiga. A la vez, son también avisos de los estados de consciencia diferentes, ya que apelan también a otros significados.

Comenzando por el nombre del padecimiento, el mal y la condición febril que éste implica evocan el mal de la selva, llamado también la fiebre de la selva. Las narraciones sobre este enigmático mal circulan tanto en forma oral, como escrita en muchas zonas selváticas de América Latina ${ }^{5}$. Según cuentan las leyendas, los afectados empiezan a desvariar sin ninguna razón aparente, se muestran visiblemente deprimidos o desesperados, hasta llegar a un estado que se asocia frecuentemente con el frenesí sexual, que es cuando rompen la ropa que traen puesta y se empeñan en actividades 
autodestructivas $^{6}$. A la inversa, el frenesí amoroso también se denomina frecuentemente con el nombre del mal de la selva. En la adjudicación de este nombre al delirio amoroso influyeron posiblemente las ideas deterministas de los finales del siglo XIX, según las cuales las zonas tropicales, cuya máxima expresión es la selva, son las más propensas para el desarrollo de las pasiones sexuales.

Paradójicamente, el desarrollo del tema de la locura provocada por la obsesión amorosa ocurre en esta novela en los confines nórdicos del planeta. En una entrevista, Rivera Garza explica las razones de su elección: "Si esa cosa ajena a ti: llámese el deseo o la pasión, toca un día a tu puerta, es para ir a lugares que no conoces $^{7 "}$. Resulta obvio que la taiga y no la selva, siendo un territorio aún más hermético y distante que el bosque tropical, le resulta a la autora más útil para construir una metáfora de las regiones desconocidas de la naturaleza humana. No obstante, la metáfora conocida entre muchos lectores latinoamericanos como mal de la selva debe hacer la conexión con el título de la novela, mandando el primer aviso sobre el tema de la obsesión destructiva.

En un principio, la fuga de los amantes puede parecer lógica ante la sugerida falta de amor en el matrimonio - por lo menos así le parece a la detective narradora al comienzo de la historia. Sin embargo, a medida que los amantes se introducen en lo silvestre y las huellas de la civilización se van borrando, su pasión llega a niveles destructivos. Su actitud llega a ser considerada demente por los habitantes del poblado en el que los prófugos se establecen por un tiempo. La contrariedad de esos pobladores surge porque los amantes trasgreden ciertas reglas que existen en su sociedad, por más primitiva y apartada de la civilización esta que parezca. Aún en este el lugar existe una cultura. Los lugareños se muestran hospitalarios con los forasteros al entregarles una cabaña y convidar con ellos su escasa comida. Sin embargo, éstos no corresponden su amabilidad. Su entrega absoluta a la pasión y su despreocupación por las costumbres de los locales causan tensión en la aldea. El frenesí es un mal ejemplo, por eso los niños de la aldea tienen prohibido acercarse a la cabaña de "los locos" y las mujeres se avergüenzan por entrar en contacto con ellos. $\mathrm{Su}$ aversión es tan grande que se extiende hacia la detective y el traductor, a pesar de su hospitalidad: "Cuando la cerraron a nuestras espaldas y se alejaron a toda prisa quedó muy claro que deseaban evitar todo contacto con cualquier cosa o persona que tuviera algo que ver con lo que ellos llamaban 'el matrimonio de la taiga"” (Riverza Garza 2012: 41-42).

La tensión provocada por el comportamiento sexual obsesivo de los "locos de la taiga" provoca violencia en el pueblo. El problema se suscita cuando el frenesí amoroso despierta fascinación en el individuo salvaje que vivía libremente alrededor del caserío. Los villanos estaban acostumbrados a la presencia de él, le daban de comer a veces y lo dejaban dormir en un granero durante el invierno. Su presencia no era ningún problema hasta la llegada de "los locos". Cuando la gente del pueblo se da cuenta de la fascinación de este joven con los amantes a los que espía día y noche, lo empiezan a percibir como una amenaza. La narradora resalta el hecho de que el personaje ya no era un niño como el protagonista de la película L'enfant sauvage (1970) de François Truffaut, sino un adolescente. Su obsesión por espiar a los amantes a la edad del despertar biológico le ha de costar la vida. Aunque no se explican claramente las circunstancias de su muerte, se infiere que fueron los leñadores los que se la han dado. Son ellos los que lo traen todo ensangrentado y embarrado en la esperma y los excrementos, protestando algo frente a la cabaña que ocupan la narradora y su traductor - los nuevos forasteros que ante sus ojos han tomado el lugar de la pareja de amantes despreocupados. La muerte que sufre el muchacho señala otra locura, esta vez aplicable a los lugareños que resuelven sus problemas dándole muerte a un ser inocente. De este modo, la temida enfermedad que contraen los viajeros a los lugares extraños se confirma en El mal de la taiga, pero se extiende a situaciones múltiples, que atañen tanto a los extraños como a los propios del lugar. 


\section{La mujer arquetípica}

Aunque el calificativo de "locos" se aplica en la novela a los dos amantes, el problema le atañe principalmente a la mujer, puesto que es ella el centro de la atención de toda la historia y el motivo del viaje a la taiga. El amante se menciona muy pocas veces y la atribución de la locura en su caso puede resultar ambigua. Según los criterios de la sociedad patriarcal, vigentes desde la época prehistórica, la pasión sexual del hombre se explica por el anhelo de corroborar su potencial masculino, que es justamente lo que se espera de él (Freud 1930: 84-86). Sin embargo, no es igual el caso de la mujer. De acuerdo con lo que expresan Gero y Conkey en su estudio sobre la construcción del rol femenino en la prehistoria,"[l]os primeros modelos de rol de género en la mujer se asocian principalmente con la capacidad biológica de la maternidad (fertilidad, gestación y lactancia) y su papel determinante en la crianza de la descendencia"(1991: 48). Por tanto, la expresión máxima de la feminidad, sobre todo en las sociedades primarias - que es a donde pretenden llegar los amantes al fugarse de la civilización no es la voluptuosidad, sino la reproducción y la crianza de los hijos.

El tropo de la mujer arquetípica se incluye ciertamente en las novelas de la selva. En esas, la sensualidad de la amante que habita en el ambiente silvestre da frutos, es decir que va a parir hijos y cuidar de ellos o por lo menos es apta para ello. Sin embargo, la mujer de la taiga no es así. Ella no pertenece de manera natural a la taiga: es una forastera y lo único que le interesa es la lujuria. Pare unas criaturas, pero ella misma, junto con su amante, las destruye:

Que algo había brotado de su boca a través o junto con el vómito [...]. Que fue sólo poco a poco que lo admitieron ellos dos: algo se movía sobre el colchón. Algo levantaba la cabeza, doce o trece veces [...]. Que entre el frenesí, que entre tantos líquidos y tantos ruidos, no pudieron darse cuenta de cuándo o cómo pasó. [...]Y de ahí, con cuidado y asco confundidos, había despegado el cuerpo de dos o tres, o tal vez más criaturas pequeñitas. La sangre del vómito, que bien pudo haber sido la sangre del nacimiento, confundida ahora con la sangre de la muerte. La saliva. El excremento o las lágrimas, da lo mismo. Los huesos rotos. (Rivera Garza 2012: 74-75).

Evidentemente, la mujer falla en su rol de la madre. El acto de vomitar a las criaturas evoca claramente la imagen de Cronos, quien obligado por Zeus vomita a sus hijos que ha devorado. Sin embargo, al contrario de los Titanes, los hijos de la pareja de la taiga quedan destruidos físicamente por la obsesión sexual de sus progenitores o se pierden en el mundo y re-aparecen siendo explotados en un prostíbulo.

La insania de la mujer causa estragos en su conciencia. Pruebas de ello son las noticias que le envía a su marido de los lugares por los que transita con su amante. Él las interpreta como llamadas de auxilio, por eso contrata a la detective para que la encuentre y la traiga de regreso a casa. Su razonamiento es parecido a la voluntad del rescate de un ser querido de una adicción narcótica o alcohólica y señala la victimización de la persona que cayó presa de sus obsesiones sin saber cómo resolver el problema. Sin embargo, ella no se retracta ni siquiera por la pena que le da al recordar el destrozo de sus críos. Sigue empecinada en no regresar a la civilización, como "[a]lguien[que] añoraba una forma de libertad que era en realidad un abismo" (Rivera Garza 2012: 73). Su pasión amorosa lleva un precio alto: los amantes tienen que sacrificar cualquier vida social, ya que sus obsesiones no están bien vistas por ninguna cultura, por más primitiva que esta sea. Además, tienen que cargar con la culpa de destruir a sus propios hijos y contribuir a la tragedia de otros, representados en la novela por el muchacho feral. En el lenguaje metafórico de la novela, esa exclusión se traduce en su internamiento en el bosque inhóspito, en el que tienen que sacrificar hasta las comodidades básicas que brinda la civilización tales como el agua, la comida, la vestimenta y los servicios del baño. La protagonista de esta parte de la historia evidentemente no llena el arquetipo de la mujer ligada a la naturaleza primitiva. Al contrario de sus anteriores modelos de la selva, ella no es una madre, su actividad sexual no lleva a la 
reproducción y continuación del género humano, sino más bien a una degeneración.

\section{Las criaturas fantásticas}

La travesía hacia dentro de los lugares herméticos siempre implica miedos, lo cual fructifica en las historias con la presencia de seres extraños: sean sirenas, elfos, espíritus del bosque, animales misteriosos u otras criaturas fantásticas. En El mal de la taiga aparecen algunas criaturas "propias" de la novela y "prestadas" de los cuentos infantiles europeos, tales como Hansel y Gretel, la Caperucita y el lobo feroz, cuyo escenario son los bosques templados. Las que son exclusivas de este texto son poco convincentes en su rol de fantásticas. Aunque la narradora se refiere a ellas solamente como "criaturas", no hay duda que se trata de los frutos de la relación sexual del "matrimonio de la taiga". Por tanto, se trata de sus hijos, por más extraños que parezcan. La narradora afirma que es "difícil describir lo que no se puede imaginar" (Rivera Garza 2012: 84), lo cual puede ser cierto, puesto que se trata de la escena que ella presencia en el prostíbulo. Según la narración, las criaturas que la ejecutan podrían ser niños o enanos siendo explotados por otras personas.

En cuanto a las figuras de los cuentos infantiles, la narradora las evoca sin una razón aparente y reflexiona sobre las diversas versiones que hay de ellos. Sus divagaciones indican que los arquetipos sufren transformaciones según la época y la fantasía de los que los reviven; asimismo sugiere que éstos pueden cobrar una dimensión nueva, acorde a los intereses de la historia. En efecto, los protagonistas de la novela incorporan algunos elementos de aquellos cuentos infantiles, cuyo propósito - según observa Bruno Bettelheim - era prevenir a los jóvenes ante los peligros del mundo. Los sucesos dramáticos, cuyo final frecuentemente no era feliz, debían ser advertencias para los niños ante la idea de adentrarse sin supervisión a los lugares desconocidos, metafóricamente representados en el bosque. El elemento de la amenaza, frecuentemente exagerado, debía impresionarlos y fijar en sus mentes la advertencia ${ }^{8}$.

Hansel y Gretel, inmortalizados por los hermanos Grimm, cobran una vida nueva en la novela de Rivera Garza en la pareja de los amantes. Su razón para internarse en el bosque es diferente dela que tenían los niños de aquel cuento, sin embargo su ambular sin dirección por la taiga los iguala a aquéllos en su vulnerabilidad ante los peligros que implica lo desconocido. Algunos moradores del bosque se refieren a ellos como "la muchachita y el muchacho" (Rivera Garza 2012: 59). La mujer tiene una apariencia que podría ser la versión adulta de la niña Gretel. La pareja parece satisfecha y feliz con su situación: "Hansel y Gretel podrían haber tenido una sonrisa así de enorme, así de contundente. Así de serena, tal vez" (Rivera Garza 2012: 105). Su candor despierta cierta empatía, sin embargo, la narradora es pronta en recordar que se trata de personas adultas, cuya actitud más que infantil resulta irresponsable y dañina. La nueva versión de los "niños extraviados" termina aún más desconsoladora que las anteriores, ya que su viaje a la naturaleza desconocida provoca desastres. Además, no hay ayuda que se les pueda prestar, ya que el problema es causado justamente por su obsesión de seguir perdidos, de modo que ellos mismos impiden su posible rescate. Es por eso que la detective no insiste en traer a la mujer de regreso a la urbanidad: según afirma, sabe reconocer la causa perdida y se regresa a su ciudad sin haber cumplido su misión.

La Caperucita también encuentra su correspondencia en la novela. La protagonista, al igual que la niña del cuento, destaca por el uso del color rojo, símbolo de la atracción sexual: "El fotógrafo había capturado segundo a segundo la manera en que la mujer daba vueltas sobre su propio eje. El vestido rojo, abierto. La sonrisa otra vez. Y atrás, atrás sobre todo eso, el bosque" (Rivera Garza 2012: 19). También hay un lobo que entra en contacto con la sujeto, pero el desenlace de su aparición resulta diferente del cuento infantil. Su presencia en la versión de los Grimm ponía a la niña en una situación de escoger entre el deber de llevarle la comida a la 
abuelita y el placer de disfrutar del mundo que la rodeaba. Cuando se deja llevar por la sugerencia del placer, provoca la perdición tanto para ella como para su abuela. Su salvación llega cuando aparece el cazador que le abre la panza al animal y rescata a las dos víctimas. La emergencia de la Caperucita se interpreta como un renacer en una mujer joven, madura, quien aprende de su experiencia y en la próxima situación similar ella misma sabe defenderse. En cambio, el lobo que aparece en el la novela de Rivera Garza no establece el hito en el desarrollo de la protagonista, sino que es un elemento fijo de la vida que ella eligió:

Que no dejaba aproximarse a nadie a la cabaña. Que
daba vueltas a su alrededor, como si el círculo que
formaban sus patas sobre la tierra o, eventualmente,
sobre la nieve, les sirviera de escudo contra algo
más o los protegiera de algo que venía tal vez del
bosque mismo. Que el lobo, cuando descansaba, se
lamía una a una las patas. (Rivera Garza 2012: 44)

La presencia de este lobo o más bien lobezno, como recalcan los supuestos testigos, señala la perduración de las obsesiones de la pareja. Al contrario de lo que ocurre en el cuento de los hermanos Grimm, en la experiencia de esta nueva Caperucita no ocurre ninguna transformación: ella se afirma en su obsesión de seguir entregada a la pasión amorosa, aún a pesar de la sacudida que le causa la consciencia de hacer el mal a sus hijos.

En cambio, hay en la novela otro lobo, que acecha a la narradora. Éste aparece en el texto cada vez que la detective acumula sus propios temores o siente lo inadecuado de sus sentimientos de atracción sexual o morbo. Una de esas situaciones ocurre en el contexto de la espera del acto estelar en el bar- prostíbulo, cuando se siente algo borracha, al tiempo que describe su propia imagen del espejo con cierta semblanza de Gretel y se percata de la belleza de su acompañante, el traductor. En este momento en su narración surge la imagen del lobo:

Recuerdo el salto del lobo. La manera en que sus patas traseras se despegaron muy lentamente de la nieve mientras las delanteras, suspendidas en el aire, parecían querer alcanzar algo más. Recuerdo que vi, justo en ese momento, la imagen otra vez. Un lobo maduro y grande; un lobo de un pelaje descomunal, saltando hacia algo que todavía no lograba discernir pero que estaba, con toda seguridad, ahí, en la siguiente imagen. Abajo, de todas maneras, se seguía deslizando el hilillo rojo que, al toparse con el tronco del mismo majestuoso abeto, ascendía entonces hacia los aires. (Rivera Garza 2012: 84)

Sin embargo, el enigmático lobo no es exclusivo de la taiga. Al regresar a la ciudad, la detective vuelve a ver al marido burlado quien le encargó la misión de traer de regreso a su esposa. El hombre le gusta y es en el contexto de esta atracción que el lobo la ataca. Es un animal que se escapa del zoológico, sin embargo las líneas finales de la novela hacen pensar que tanto el lobo, como el bosque son metáforas que usa la narradora para referirse a la naturaleza humana que sigue siendo igual en todos los tiempos y lugares: "Todos llevamos un bosque dentro, en efecto. Kilómetros y kilómetros de abedules, abetos, cedros. Un cielo gris. Las cosas que no cambian. Supuse que saltaría de un momento a otro. Vi sus fauces, su saliva, sus dientes" (Rivera Garza 2012: 117). Cabe subrayar que el asalto ocurre en la ciudad, de modo que el tropo del viaje a la naturaleza virgen sufre un trasplante, con lo cual se subraya el carácter paródico del periplo.

\section{Conclusión}

En suma, aunque los tropos del viaje a la naturaleza virgen empleados por Cristina Rivera Garza en su novela no son nuevos, confieren significados originales al exhibir un giro paródico al respecto de los que se han usado en otros textos literarios. Su función, como se ha mencionado en la introducción de este trabajo, no es lúdica, sino transformativa y/o complementaria. Con la apropiación y el consecuente desplazamiento de los motivos conocidos, la autora es capaz de expresar preocupaciones sobre la naturaleza del ser humano y el efecto destructivo de sus acciones tanto en el contexto de las vidas individuales, como en el del medioambiente. 
Según se ha demostrado, el tropo de la penetración de la naturaleza primitiva aparece en El mal de la taiga en el contexto de dos parejas y alude a por lo menos dos problemas distintos. Por un lado, el adentramiento por parte de los amantes es una metáfora de perderse entre las pasiones y las obsesiones del cuerpo. A pesar de que los dos aludidos aparentan estar contentos con su libertad, no logran una felicidad completa. Su manumisión cuesta sacrificios y sus acciones terminan dañando tanto a ellos mismos, como a otros seres. $\mathrm{Su}$ precio es la exclusión de la sociedad civilizada y cargar con la consciencia de sus actos dañinos. Por el otro lado, la incursión en la taiga muestra problemas causados por la gente a sus prójimos y a la naturaleza. La introspección hace ver que aún en el ambiente más primitivo existe la explotación de los seres más débiles por los más fuertes, además se reportan varios problemas causados por los humanos al ambiente natural. Entre ellos, la tala excesiva de los árboles y la actividad febril de los buscadores de oro y minerales, sobre todo del petróleo. En una visión futurista, se proyecta la desalentadora imagen de la ciudad de metal que pronto va a construirse sobre el lago de la todavía prístina región.

El tropo de la enfermedad, anunciado desde el título como el mal de la taiga, adquiere en el texto significados múltiples. No solo es la afección temida por los viajeros a los parajes apartados, sino que se refiere a los daños que causan las obsesiones humanas, también múltiples. Por un lado, se trata de las pasiones sexuales que dañan moralmente a los mismos individuos y a los que los rodean; por otro, es la gula por el enriquecimiento, que crea diferencias abismales entre los estándares de vida de los capitalistas y los obreros; en un tercer plano, se trata de la destrucción del medioambiente. El mal que afecta a todos en la taiga como espacio geográfico, así como referente metafórico es la insaciabilidad que destruye las diversas formas de vida del planeta.

La mujer arquetípica que aparece en otros textos del viaje a la naturaleza como una orgullosa dadora de vida, en esta novela no llena el paradigma de la "hembra natural". Su voluptuosidad no lleva a nada más que la lujuria. Esta mujer falla en el rol de la madre no solo al parir unas criaturas extrañas, sino sobre todo al no saber cuidar de ellas y destrozarlas, aunque sea de manera involuntaria.

Por último, el tropo de las criaturas fantásticas también sufre una transformación. Los caracteres de los cuentos infantiles como Hansel y Gretel, y La Caperucita Roja se mencionan con una sobria reflexión sobre su papel dentro de la narrativa infantil europea. A su vez, los pequeños seres que aparecen no son más que eso: unas criaturas de escaso tamaño, que bien podrían ser niños o enanos. La única criatura que pertenece al mundo natural y sin embargo aparece dentro de la ciudad es el lobo que asalta a la detective-narradora.

En suma, la transformación de los tropos del viaje a la naturaleza virgen que se comentaron en este trabajo, le permite a la autora expresar ideas nuevas y expresarlas con el uso mínimo de las palabras. Como destaca el análisis, estos significados convergen en marcar que el egoísmo y el ensimismamiento de los individuos causan daños irreversibles a todas las formas de vida. A pesar de la fragmentariedad del texto, resulta obvio que la obra, aunque breve, plantea interrogantes de carácter ético sobre las acciones humanas al respecto del cuerpo humano y el espacio geográfico. Al hacerlo, se despunta la necesidad de un compromiso ético con las diversas formas de vida. Según expresa la narradora: "Es bueno recordar a veces los confines del planeta. Es bueno recordar que se vive, de hecho, en un planeta" (Rivera Garza 2012: 27). El viaje a esos confines, sea real o imaginario, realza la consciencia de que tanto el cuerpo humano, como el territorio geográfico son limitados. Los dos son representaciones de las distintas formas de vida del planeta.

\section{Notas}

La investigación necesaria para escribir este ensayo ha sido posible gracias a la beca de la Universidad Estatal de Valdosta, VSU Faculty Research SEED Grant. (The research for this essay was made 
possible thanks to a Valdosta State University Faculty Research SEED Grant).

1. La muerte me da (2007) y Verde Shanghai (2011).

2. Según Vladimir Propp, el "actante" es el sujeto que mueve la acción dentro de un cuento. Consúltese Selden, Raman, Contemporary Literary Theory (1985). Referencia incluida en "Bibliografía".

3. La característica principal de nature writing es que la naturaleza se pone en el centro de la atención como protagonista única e indisputable de la narración, ya sea como objeto de admiración o de preocupación por la explotación de los recursos naturales. Según observa Michael Branch, "the term 'nature writing' has usually been reserved for a brand of nature representation that is deemed literary, written in the speculative personal voice, and presented in the form of the nonfiction essay. Such nature writing is frequently pastoral or romantic in its philosophical assumptions, tends to be modern or even ecological in its sensibility, and is often in service to an explicit or implicit preservationist agenda" (91). Sin embargo, los acercamientos a la naturaleza se han diversificado mucho a partir de la segunda mitad del siglo XX. Algunos de los textos clasificados bajo ese nombre son: Walden (1854), de Henry David Thoreau, The Mountains of California (1894), de John Muir, Pilgrim at Tinker Creek (1974), de Annie Dillard y The Mysterious Lands (1989), de Ann Zwinger, entre otros.

4. Un giro de denuncia de las realidades sociales por medio de la literatura del viaje a la selva se observa también en la literatura europea desde el siglo XIX. En la novela El corazón de las tinieblas (1899) de Joseph Conrad, la incursión río arriba hacia dentro de la selva africana del Congo descubre el problema del imperialismo occidental, además de proporcionar elementos para las investigaciones sobre la locura. El protagonista de esta narración, un marinero británico, quiere encontrar a su amigo extraviado en el interior del Congo tras una expedición de explotación de marfil. Conforme avanza río arriba, se percata de la situación extrema en que viven los colonos europeos y su brutalidad hacia los nativos africanos.

5. Janine Potelet se refiere a esta afección presente en Canaima (1935), de Rómulo Gallegos, como la "fascinación [...] voluntad inerte [...] y un secreto e inexplicable temor" (Wylie 2009: 28).
6. Por ejemplo, la tía Matilde, en Balún Canán (1957), de Rosario Castellanos.

7. http://www.youtube.com/watch?v=16Gtymx3pyU

8. Consúltese Bruno Bettelheim, The Uses of Enchantment. The Meaning and Importance of Fairy Tales (1977).

\section{Bibliografía}

Bettelheim, Bruno. (1977). The Uses of Enchantment. The Meaning and Importance of Fairy Tales. New York: Vintage Books.

Branch, Michael P. "Before Nature Writing". (2001). Beyond Nature Writing: Expanding the Boundaries of Ecocriticism. Eds. Karla Armbruster and Kathleen.R. Wallace. Charlotesville: U of Virginia P.

Castellanos, Rosario. (1957). 2003. Balún Canán. 1957. México: Editorial Planeta DeAgostini.

Freud, Sigmund. 1930. El malestar en la cultura. $1^{\mathrm{a}}$ ed. Madrid: Alianza Editorial.

Gero, Joan M. and Margaret W. Conkey, eds. (1991). Engendering Archaeology: Women and Prehistory. Cambridge, MA: Basil Blackwell.

Hutcheon, Linda. (1985). A Theory of Parody: The Teachings of Twentieth-Century Art Forms. New York: Methuen.

Marcone, Jorge. (2007). "La fiebre de la selva: ecología de la desilusión en la literatura hispanoamericana". Centro Cultural BID. Encuentros. №. 58.

Pisonero Pérez, Arturo. (1999). El texto y sus múltiples lecturas. Xalapa: Universidad Veracruzana. 
Rivera Garza, Cristina. (2012). El mal de la taiga. México: Grupo Planeta.

Selden Raman, Peter Widdowson and Peter Brooker. (1985). A Reader's Guide to Contemporary Literary Theory. $4^{\text {th }}$ ed. London: Prentice Hall.
Wylie, Leslie. (2009). Colonial Tropes and Postcolonial Tricks: Rewriting the Tropics in the Novela de la Selva. Liverpool: Liverpool UP.

\section{(C) $10 \Theta \Theta$}

Este obra está bajo una licencia de Creative Commons

Reconocimiento-NoComercial-SinObraDerivada 4.0 Internacional. 